DOI: 10.20472/IAC.2018.001.022

\author{
WARAPONG THAKANUN \\ Suan Sunandha Rajabhat University, Thailand
}

PRAMSUK HUANPRAPAI

Suan Sunandha Rajabhat University, Thailand

\title{
THAI MASSAGE SERVICE BEHAVIOR IN RATCHABURI, THAILAND
}

\begin{abstract}
:
This research aims to study: 1) the demographic factors influencing the customers' decision and behavior to use the service of Thai massage in Ratchaburi, Thailand; and 2 ) the influence of service marketing mix factors on the customers' decision. The study was carried out between May and August 2017. This study employed a quantitative research methodology. The research sample consisted of 400 individuals who had experiences in using Thai massage services in Ratchaburi. A questionnaire was used to collect the data. The data were analyzed by descriptive statistics including frequency, percentage, mean and standard deviation, and inferential statistics. The Research result showed that 1) customers' decision and their behavior to use the service of Thai massage was influenced by age, occupation, average income per month, and education level; 2 2) service marketing mix that had an effect on the customer decision and behavior to use the service of Thai massage included, sorted in a descending order, product, process, price, place, personnel, promotion, and physical attributes.
\end{abstract}

\section{Keywords:}

Service Quality, Customer Expectation, International Tourists

JEL Classification: Y80 


\section{Introduction}

Thai Massage is well known in the world and also to Thai heritage preservation that has long history and outstanding identity which related with domestic economy in the present. Moreover, natural therapy popular waving is too. So that, The government was agree with establish Thai massage organization and develop alternative medicine that make Thai massage more importance until to create the standard cover with Massager, Location and Spa too for acceptance and to be international standard. Almost reason that the tourists are interest in Thai massage is relax and tension treat that they will come back again with body massage for the most, also to recommend other to people to know too. Researcher think if Thai massage entrepreneur know about the factors that affect to tourist decision which the owner can be adaptable such as Choose the products, Personal training, Marketing Plan etc. for meet customer demand both with Thai and foreigner. Because if the entrepreneur doing the business but do not know the customer demand that difficult to successful

\section{Instrumentation research Process}

Part 1 Personal data analysis

Personal data of the sampling which are sex, ages, status, education, career and income per month that distribution number and percentage are found that almost of the sampling is male for there are 167 peoples or 41.8 Minor is female there are 233 peoples or 58.3 percentage.

Ages found that almost of the sampling is who are between 30-40 years old or 48.3 percentage. Minor is who are between 41-50 years old there are 103 peoples or 25.8 percentage and lower than 30 years old there are 76 peoples or 19.0 percentage by random order.

Education found that almost of the sampling was graduated in bachelor degree for the rearr 316 peoples or 79.0 percentage. Minor is more than bachelor degree there are 45 peoples or 11.3 percentage and lower than bachelor degree there are 39 peoples or 9.8 by random order.

Career found that almost of the sampling is government personal for there are 142 peoples or 35.5 percentage. Minor is private company personal there are 104 peoples or 16.0 percentage and owner business there are 83 peoples or 20.8 percentage by random order. 
Income per month found that almost of the sampling who has income between 15,001 20,000 baht per month for there are 151 peoples or 37.8 percentage. Minor is income between $20,001-25,000$ baht per month for there are 115 peoples or 28.8 percentage. And income between 10,001 - 15,000 baht per month for there are 65 peoples or 13.3 percentage by random order.

Marketing Mix consist of massage product factor, service process factor, price factor, personal factor, place factor, marketing mix factor and physical factor.

table 1 mean and standard deviation of service quality factor

\begin{tabular}{|c|c|c|c|}
\hline Quality Service & $\bar{X}$ & S.D & Result \\
\hline \multicolumn{4}{|l|}{ 1. massage product factor } \\
\hline The product is safe for the body & 4.28 & .448 & Highest \\
\hline Standardized Products Ministry & 4.29 & .457 & Highest \\
\hline Products from the folk wisdom & 4.33 & .470 & Highest \\
\hline Natural products & 4.24 & .426 & Highest \\
\hline totally & 4.28 & .290 & Highest \\
\hline \multicolumn{4}{|l|}{ 2. service process factor } \\
\hline The service quality and standards & 4.30 & .458 & Highest \\
\hline There are a variety of services & 4.23 & .420 & Highest \\
\hline convenient to pay & 4.25 & .434 & Highest \\
\hline totally & 4.25 & .320 & Highest \\
\hline \multicolumn{4}{|l|}{ 3.Price factor } \\
\hline Suitable Price with quality service & 4.23 & .421 & Highest \\
\hline The service fee is clearly stated & 4.31 & .462 & Highest \\
\hline Standard Price & 4.21 & .408 & Highest \\
\hline totally & 4.24 & .339 & Highest \\
\hline \multicolumn{4}{|l|}{ 4.Personal Factor } \\
\hline Experience,Professional and Knowledge & 4.31 & .464 & Highest \\
\hline Good personality and relationship & 4.23 & .420 & Highest \\
\hline Service mind & 4.21 & .406 & Highest \\
\hline Communication skills & 4.13 & .334 & High \\
\hline healthy & 4.26 & .439 & Highest \\
\hline totally & 4.22 & .239 & Highest \\
\hline \multicolumn{4}{|l|}{ 5.Place Factor } \\
\hline safety & 4.22 & .415 & Highest \\
\hline comfortable for transportation & 4.16 & .369 & High \\
\hline near community & 4.30 & .459 & Highest \\
\hline totally & 4.22 & .279 & Highest \\
\hline
\end{tabular}




\begin{tabular}{|c|c|c|c|}
\hline \multicolumn{4}{|l|}{ 6.Promotion Factor } \\
\hline Diversity advertisement & 4.22 & .415 & Hiahest \\
\hline Interested Promotion such as discount & 4.20 & .402 & High \\
\hline any promotion for free such as manicure & 4.29 & .455 & Highest \\
\hline totally & 4.23 & 319 & Highest \\
\hline \multicolumn{4}{|l|}{ 7.Physically factor } \\
\hline $\begin{array}{l}\text { The shop is not too narrowAnd there are } \\
\text { enough massage rooms }\end{array}$ & 4.15 & .360 & \\
\hline Interested decoration & 4.23 & .423 & Highest \\
\hline Herb Aroma & 4.33 & .472 & Highest \\
\hline clean equipment & 4.21 & .406 & Highest \\
\hline totally & 4.22 & .415 & Highest \\
\hline Service quality for totally & 4.24 & .188 & Highest \\
\hline
\end{tabular}

From table 1 opinion analysis result on service quality in the holistic all in high with mean at 4.24. When was considered in each factor found that massage product, service process, price, personal, place, promotion and physical factors showed that all in highest level with mean $4.28,4.25,4.24,4.22,4.22,4.23$ and 4.22

\section{Service Behavior}

Table 2 Mean and Standard Deviation of time number to serviced with Thai massage

\begin{tabular}{l|l|l|}
\hline $\begin{array}{l}\text { time number to serviced with Thai } \\
\text { massage }\end{array}$ & $\begin{array}{l}\text { number } \\
\text { (people) }\end{array}$ & percentage \\
\hline 1). 1 time per a week & 48 & 12.0 \\
2). 2 - 3 time per a week & 16 & 4.0 \\
3). 1 time per a month & 142 & 35.5 \\
4). Not sure & 194 & 48.5 \\
\hline totally & $\mathbf{4 0 0}$ & $\mathbf{1 0 0 . 0}$ \\
\hline
\end{tabular}

From table 2 found that almost of the sampling has Thai massage behavior not sure for there are 194 people or 48.5 percentage. Minor is 1 time per a month there are 142 peoples or 35.5 percentage and 1 time per a week there are 48 peoples or 12.0 percentage by random order. 
Table 3 Mean and Standard Deviation of Thai massage expense

\begin{tabular}{l|l|l|}
\hline Thai massage expense & $\begin{array}{l}\text { number } \\
\text { (people) }\end{array}$ & percentage \\
\hline 1). Less than 300 baht & 222 & 55.5 \\
2). $300-400$ baht & 84 & 21.0 \\
3). $401-500$ baht & 77 & 19.3 \\
4).More than 501 baht & 17 & 4.3 \\
\hline totally & $\mathbf{4 0 0}$ & $\mathbf{1 0 0 . 0}$ \\
\hline
\end{tabular}

From table 3 found that almost of the sampling are expense with Thai massage less than 300 baht for there are 222 peoples or 55.5 percentage. Minor is $300-400$ baht there are 84 peoples or 21.0 percentage and 401.500 bath there are 77 peoples or 19.3 percentage by random order.

Table 4 Mean and Standard Deviation on personal decision with Thai massage service

\begin{tabular}{l|l|l|}
\hline $\begin{array}{l}\text { personal decision on Thai massage } \\
\text { service }\end{array}$ & $\begin{array}{l}\text { number } \\
\text { (people) }\end{array}$ & percentage \\
\hline 1). parent & 34 & 8.5 \\
2). cousin & 8 & 2.0 \\
3). friend & 39 & 9.8 \\
4).by themselves & 263 & 65.8 \\
5).other & 56 & 14.0 \\
\hline totally & $\mathbf{4 0 0}$ & $\mathbf{1 0 0 . 0}$ \\
\hline
\end{tabular}

From table 4 found that almost of the sampling has the person who affected to service decision on Thai Massage are by themselves for there are 163 peoples or 65.8 percentage. Minor is friend there are 56 peoples or 14.0 percentage and the other there are 56 peoples or 14.0 by random order.

Table 5 Mean and Standard Deviation on Thai massage reason to serviced

\begin{tabular}{l|l|l|}
\hline Thai massage reason to serviced & $\begin{array}{l}\text { number } \\
\text { (people) }\end{array}$ & percentage \\
\hline $\begin{array}{l}\text { 1). Suitable price when compare with } \\
\text { service }\end{array}$ & 132 & 33.0 \\
2). Staff ability & 172 & 43.0 \\
3). Safety service & 69 & 17.3 \\
4). Comfortable transportation & 27 & 6.8 \\
\hline totally & $\mathbf{4 0 0}$ & $\mathbf{1 0 0 . 0}$ \\
\hline
\end{tabular}

From table 5 found that the most reason to serviced with Thai massage is staff ability for there are 172 peoples or 43.0 percentage. Minor is suitable price when compared with 
service there are 132 peoples or 33.0 percentage and safety service there are 69 peoples or 17.3 by random order.

\section{Summary and Conclusions}

From service behavior on Thai Massage shops in Ratchaburi,Thailand with demography characteristic. The research result showed that the sampling who was different with sex, ages, status, education and career has Thai service behavior on expense per a time and service frequency time per a month are differently that related with research Anchalee Sukanonsawat who was studied on Alternative: Factors correlated customer "s behavior and behaviors treand on using the services of Royal River Hotel. Found that service frequency in a year ago are different with sex, education and income per a month. And also to related with the research result of Sirattchanon Chutikarnchitipat who was studied on The factors that related with customer service behavior of Grate Spa Beauty Clinic in Ratchaburi found that demography characteristic customer which are ages, status, education, career and income per month are different also to expense service factor and service frequency per month are different as well.

For Massage product factor, the customer has attitude toward marketing mix cover with service trade and massage service in highest level. When was considered in each factors found that the customer has attitude at highest level on product is safety and has ministry standard also from local wisdom and as natural product. For service process factor, The customer has attitude on marketing mix and service process factor are in highest level. When was considered in each factors found that service quality on standard also to diversity service and comfortable payment. For price factor, The customer has attitude on marketing mix and price factor are highest level. When was considered in each factors found that the highest customer attitude are suitable price when compared with service and clearly price also to on standard. For personal factor, the customer has attitude on marketing mix in personal factor is highest level. When was considered in each factors found that the highest customer attitude are experience, professional and has knowledge also has good personality and relationship, service mind and healthy.

For place factor, the customer has attitude on marketing mix in place factor is highest. When was considered in each factors found that the highest customer attitude are safety and near the community area. For promotion factor, the customer has attitude on marketing mix in promotion factor is highest. When was considered in each factors found that the highest customer attitude are diversity advertise and has other promotion that interested such as discount. And finally are physically factor. the customer has attitude on marketing mix in physical factor is highest. When was considered in each factors found that the highest customer attitude are interesting decoration, herb aroma and clean equipment. 


\section{Service Quality}

Thai Massage Shop in Ratchaburi almost has safety products and ministry standard with natural material, Service process has quality and standard, Comfortable to pay, Suitable Price and Clearly, Personal has experience Professional Personality and good relationship also to service mind, communication skills. Almost of location is near the community. Marketing Plan has advertisement in diversity media. There are interesting promotion such as discount and other special service like nail decorate for free. For Physical factor has enough massage rooms, widely, clean, beauty decorate, good smell with any kind of herbs and clean equipment. Main reason to prefer Thai Massage is Personal ability, price, suitable price when compare with service quality and trust in the safety.

\section{References}

Boomtham Kitpredaborisut. 2006. Research Methods in Behavioral and Social Sciences. Bangkok: Wattanapanich.

Philip Kotler and Gary Amstrong. 1990. Market an Introduction (New Jersey: Prentice-Hall, Inc.Second Edition

Kalaya Vanichbancha. 2003. Statistical analysis: statistics for decision making. 5th edition. Bangkok: Chulalongkorn University Press.

Nattapong Techarattanaset. Factors infiuencing consumer choice at S\&P restaurants in the Bangkok. Thesis of master degree of Srinakarintarawirot Phasanmit University.

SiriwanSereerat. Customer behavior. Bangkok: Wisitpattana printed.

Sittichai Thamsanae. Spa business administration in Chonburi province. Bangkok

Thapanarak Inchuanjiew. Demographical Factors, Happiness, and Work Motivation as Correlated with the With the Work Efficiency of Personnel at the Department of Vocational Education. Thesis of master degree of Ramkhamhang University.

Weerapong Chaloemjirarat. Service quality service. Bangkok: Phachachoncompany.

Yamane, Taro. 1967.Statistics: An Introductory Analysis. New York: Harper \& Row. 